\title{
DE TOEKOMST VAN DE HOUTEXPLOITATIE IN SURINAME
}

DOOR

\section{JUNKER}

Veertig jaren geleden gaf de aanleg van den spoorweg de regeering aanleiding tot haar eerste bemoeienis met het boschbezit van Suriname. Men koesterde groote verwachtingen omtrent den houtrijkdom der bosschen, die, door den spoorweg uit hun isolement verlost, ter beschikking van de industrie gesteld zouden worden. Ook op het van den beginne aan dubieuze rendement van den spoorweg, die door een onbewoond land loopend het alleen van de goudindustrie moest hebben, waren de gedachten gevestigd; een druk houtvervoer zou de inkomsten opvoeren en zoodoende het risico dat men had genomen aanmerkelijk hebben kunnen verminderen. Deze overwegingen gaven aanleiding den gepensioneerden Oost-Indischen houtvester A. M. Berkhout met de opdracht te belasten in Suriname een onderzoek in te stellen naar de wenschelijkheid voor het nemen van een proef aldaar voor een geregeld boschbeheer. In het midden van het jaar 1903 werd een aanvang met het onderzoek gemaakt. Dr. Berkhout bezocht eerst de bosschen die reeds gedurende den slaventijd ten behoeve van de houtexploitatie in gebruik waren genomen om daarna zijn bijzondere aandacht aan de langs den in aanleg zijnden spoorweg gelegen bosschen te wijden. De op de verzamelde gegevens gefundeerde gevolgtrekkingen werden neergelegd in het rapport over de Surinaamsche bosschen (1).

Op de grondslagen der conclusies van dit rapport werd op het einde van 1904 een begin gemaakt met de inrichting van een boschwezen voor Suriname. Als voornaamste taak van dezen dienst werd, teneinde de levensvatbaarheid daarvan aan te toonen, de inrichting van een proef-houtexploitatie beschouwd. Deze is op een mislukking uitgeloopen; niettegenstaande een driejarige voorbereiding moest de proefaankap in 1909 voor een gedeelte en in 1910 geheel en al gestaakt worden. 
Omdat men geneigd is het woord mislukking reeds bij voorbaat synoniem met Suriname te verklaren, eischt de juiste beoordeeling van deze aangelegenheid eenige nadere beschouwing. In de eerste plaats moet opgemerkt worden, dat de Heer Berkhout noch met de goede bosschen in het Oosten der Kolonie, noch met de Morabosschen in het Westen kennis gemaakt heeft. Ook de houtvesters, die met de voorbereiding voor den aankap waren belast, hebben zich tot de onmiddellijke nabijheid der savannazone bepaald. Zoowel het zoogenaamde Agiracomplex als ook de in het stroomgebied der Marshall-kreek onderzochte terreinen en de bosschen langs den spoorweg, waarin tenslotte de onderneming werd ingericht, behooren tot het randgebied der savanne. Verder moet opgemerkt worden, dat het gestudeerde personeel aan hetwelk de inrichting van het Boschwezen toen werd toevertrouwd geen practische ervaringen van exploitatie en exploratie van tropische wildbosschen bezat, slechts op de op Java in de Djatibosschen opgedane ervaringen kon voortbouwen. Het boschwezen in N.O.I. had zich namelijk tot 1910 stelselmatig afzijdig gehouden van elke eenigszins intensieve bemoeienis met de exploitatie van de oerbosschen in de buitengewesten. In zijn tweede verslag (over het Surinaamsche Boschwezen) doet Dr. Berkhout dit uitkomen, waarmede erkend wordt, dat de houtvesters destijds voor een moeilijk op te lossen probleem werden geplaatst. In dit verslag lezen wij o.m.: „Waar in Oost-Indië eerst een begin is gemaakt met het beheer der bosschen op de buitenbezittingen kan men van daar geen personeel ontbieden, dat grondig op de hoogte is van de exploitatie dier bosschen" (2).

Ook Dr. E. K. Plasschaert, een van de houtvesters die de houtexploitatie in Suriname hebben ingericht, heeft in zijn proefschrift nog toegegeven, dat men geen speciaal op ervaring berustend plan ten uitvoer heeft gebracht - „Es war eine Nachahmung der Djatiholz Exploitation auf Java" (3).

Tenslotte bewijst het voorstel van Dr. Berkhout, nabij de terreinen waarop de houtkap zou worden uitgeoefend, een honderdtal Javanen te vestigen, dat inderdaad de nabootsing van Indische toestanden werd nagestreefd.

In de compilatie Boschexploitatie in Suriname (4) geeft de houtvester J. W. Gonggrijp de volgende oorzaken voor de mislukking der Gouvernements-houtkapproef op:

1. Het feit, dat de waarde van het hout steeds te hoog is getaxeerd. De hooge prijs (kostprijs van het hout) van $f 35$,en $f 25$,- per $\mathrm{M}^{3}$ kon te Paramaribo niet worden opgebracht. 
2. De omstandigheid, dat de getaxeerde hoeveelheid van \pm $10 \mathrm{M}^{3}$ vierkant bekapt hout per hectare in het grootste gedeelte van het complex Montanamijn en van $7 \mathrm{M}^{3}$ in het gedeelte dat geëxploiteerd is, wel werd aangetroffen, doch voor ongeveer de helft bestond uit houtsoorten, welke geen marktwaarde hadden.

3. De omstandigheid, dat het uitsleepen door handenarbeid zoowel als met behulp van dieren, te veel voorbereiding eischte, te veel tijd in beslag nam en daardoor te kostbaar werd.

Wanneer de samensteller van het bulletin de oorzaken in de omgekeerde volgorde zou hebben genummerd en zoodoende zou hebben doen uitkomen, dat voor het in het bosch gekapte, ten deele niet marktwaardige hout een te hooge prijs werd betaald, dan zou het voor een buitenstaander duidelijker zijn geweest waarom het uit den proefaankap afkomstige hout te Paramaribo slechts met groot verlies verkocht kon worden. Men wilde (ofschoon de oorzaak toch in de omstandigheden gezocht moet worden en niet in de persoonlijke capaciteiten der houtvesters die de leiding hebben gehad) niet erkennen, dat er fouten waren gemaakt, vooral niet toegeven, dat men de dupe van de spoorwegpsychose en de Javaervaringen was geweest. Na de in Suriname doorloopen leerschool hebben alle drie houtvesters, die den proefkap hebben ingericht bij het boschwezen in N.O.I. de hoogste betrekkingen bekleed.

Zes jaren na de vaststelling der mislukking van den Gouvernementshoutaankap heeft de regeering de bevordering van den afzet van Surinaamsch hout in Nederland nog eens in overweging genomen. Aan den Ingenieur van den Rijkswaterstaat G. J. van den Broek werd opgedragen een bezoek aan Suriname te brengen en aldaar met de bevoegde autoriteiten middelen en wegen te beramen aan dit voornemen uitvoering te geven. Op den 31 Januari 1917 werd verslag uitgebracht (5) en werden als de voornaamste conclusies van zijn beschouwingen het volgende punten vastgesteld:

1. Om te trachten den afzet van Surinaamsch hout in Nederland te bevorderen zal noodig zijn uitbreiding der kennis van de houtsoorten en verbetering van de wijze van exploitatie.

2. Voor de uitbreiding der kennis is in Suriname noodig: voortzetting van de exploitatie en inventarisatie der bosschen en het verzamelen van herbariummateriaal; in Nederland: studie 
der botanische, microscopische en technische eigenschappen en onderzoek in de praktijk.

3. Aan het Koloniaal Instituut ware te vragen de leiding van de bestudeering der Surinaamsche houtsoorten in Nederland op zich te nemen.

4. Voor een exploitatie in het groot is de tijd nog niet gekomen; voorloopig zal de exploitatie zich kunnen beperken tot het met zorg aankappen van proefzendingen op niet te kleine schaal; geleidelijk kan zich dan, met de uitbreiding der kennis van het hout en de vermeerdering van den afzet, de exploitatie ontwikkelen.

5. Het aankappen der proefzendingen zou zoo mogelijk door een exploitatiemaatschappij onder toezicht van het Boschwezen of anders door het Boschwezen zelf moeten geschieden.

6. Voor de behandeling der proefzendingen in Nederland, voor de introductie van het hout en het zoeken van een markt zou het wenschelijk zijn te trachten de medewerking van den houthandel te verkrijgen".

Aan deze juiste adviezen was op het tijdstip van hun verstrekking reeds voor een belangrijk deel gevolg gegeven. De sedert 1910 als chef van den dienst van het Boschwezen fungeerende houtvester J. W. Gonggrijp had niet stil gezeten, doch van den beginne aan de exploitatie der bosschen in botanisch en houttechnisch opzicht krachtig ter hand genomen. In 1911 deed hij een reis naar de Corantijn, teneinde aldaar de Demerara-greenheartbosschen op te sporen. Na lang zoeken werden aan de Maratakka, een zijtak van de Nickerierivier, een aantal greenheartboomen gevonden. Twee jaren later heeft een opzichter van het Boschwezen in deze streek nog meer boomen gevonden. De groote verwachtingen die men omtrent het voorkomen van Demerara greenheartboomen in Suriname had gekoesterd, werden echter niet beantwoord; groenhartbosschen (Dr. Berkhout gebruikte dezen term in zijn tweede rapport onder punt 2 van het werkprogramma voor het Boschwezen) bestaan niet in de Kolonie. Dit moest de houtvester na een nieuwe reis naar het Nickeriedistrict in 1917 dan ook toegeven.

Van de Morabosschen, die Dr. Berkhout op dezelfde plaats in zijn rapport vermeldt, had de houtvester Gonggrijp reeds in 1911 de eerste opstandsopnamen aan de Corantijn gemaakt. De volgende werden door opzichters van het Boschwezen verricht, waarbij de Morabosschen aan de Corantijn, de Coppename en de Saramacca in kaart werden gebracht. 
Toen van de aanvankelijk met zooveel verwachtingen tegemoet geziene exploitatie van Demerara greenheart in Suriname niets terecht kwam, vestigde de houtvester J. W. Gonggrijp zijn aandacht op andere paalwormresistente houtsoorten. Dit had des te meer reden, omdat bij reeds in 1914 begonnen proeven aan het lichtschip in de Surinamemonding was gebleken, dat groenhart uit Demarara niet bestand was tegen de in onze kolonie voorkomende paalwormsoorten. Ook de in 1915 vernieuwde deuren der sluizen van het Saramaccakanaal, uit groenhart van Demarara, waren reeds in 1918 door den paalworm doorzeefd. Het feit, dat Manbarklakhout dank zij de door Prof. G. van Iterson geconstateerde aanwezigheid van kiezelkorrels, onder dezelfde omstandigheden onaangetast bleef, bracht den houtvester er toe proeven te nemen met Basralokus-hout, dat ook dergelijke kiezelkorrels bevat. Ook andere houtsoorten werden onderzocht en goed bevonden, daar echter alleen het Basralokushout in belangrijke hoeveelheden voorkomt, werd de aandacht op deze houtsoort geconcentreerd. De proeven werden met succes bekroond en ook die welke de Amerikaansche autoriteiten met de Surinaamsche paalwormresistente houtsoorten hebben genomen moeten in dit opzicht als geslaagd beschouwd worden. De in 1922 en 1923 genomen Basralokus-monsters waren in October 1925 noch in de wateren van het Panamakanaal, noch op de Amerikaansche kusten van den Atlantischen en Grooten Oceaan door paalworm aangetast.

Zooals later nog wel zal worden uiteengezet,werd in den concurrentiestrijd van twee Surinaamsche houtexportmaatschappijen de deugdelijkheid van het Baralokushout in twijfel getrokken en de in jarenlange moeizame arbeid opgebouwde goede reputatie van het Surinaamsche hout in het algemeen en die van het Basralokushout in het bijzonder ernstig in gevaar gebracht. Eenige mededeelingen omtrent Basralokus, die den lezer in de gelegenheid kunnen stellen zich een eigen oordeel te vormen, zijn daarom op haar plaats.

De Basralokus is een typische boom van het heuvelland en komt in drie variëteiten voor. In het zandgebied der Savanna en in lagere bodemformaties wordt de witte Basralokus aangetroffen; op de overgangsformaties van den bodem van het hoogere land en savanna groeit de roode soort, terwijl de zoogenaamde zwarte variëteit slechts op de oorspronkelijke verweeringsgebieden der gesteenten, (gesteenten, klei, zand zonder kwarts) der eigenlijke heuvels wordt gevonden. De benamingen houden verband met de kleuren der schors van de wortellijsten en waren 
vroeger, toen Basralokus nog een verwaarloosde Surinaamsche houtsoort was, vermoedelijk slechts bij de Boschnegers in gebruik. Deze vervaardigen uit de dikke en lange stammen der zwarte soort corjalen, die buitengewoon sterk zijn en tegen invloeden van het weer bestand. Daar het rijphout van de roode soort en, van het witte Basralokus ook het kernhout, weinig duurzaam zijn gebleken, is het begrijpelijk, dat de Boschnegers onderscheid hebben gemaakt. Bij het departement van openbare werken werd blijkbaar niet op deze bijzonderheden gelet en de onaangename ervaringen welke men dientengevolge opdeed leidden tot een ongunstig oordeel over al het hout van deze soort. Een andere oorzaak van teleurstelling was het gebruik van niet met zorg behandeld hout. Bij voornoemd departement wordt geen hout opgeslagen en gedroogd, worden geen eischen voor behandeld hout bij leveringen gesteld, doch dit zooals het in het bosch is bewerkt of van den zaagmolen komt ruwweg verbruikt. Uit een en ander blijkt, dat men om goede resultaten te bereiken zoowel op den aankap als ook op het bewerken van het hout deskundig toezicht dient uit te oefenen. Daarmede komen wij weer op het verslag van den Ingenieur v. d. Broek terug.

Zooals reeds gezegd is, werd de exploratie der bosschen door den houtvester J. W. Gonggrijp ter hand genomen, die haar krachtig doorzette en ook ernstige pogingen deed tot plaatsen van proefzendingen. Dr. A. Pulle had de bewerking van het verzamelde botanische materiaal op zich genomen en op uitnoodiging van den Minister van Koloniën werd door het Koloniale Instituut te Amsterdam de Commissie van Advies en Onderzoek inzake Surinaamsche Houtsoorten ingesteld. Deze Commissie maakte een aanvang met de studie der microscopische en technische eigenschappen van de grootendeels door den houtvester J. W. Gonggrijp verzamelde houtsoorten. Het resultaat van deze onderzoekingen is in de door den deskundige der Commissie, Dr. Ir. J. Ph. Pfeiffer, samengestelde publicatie „,De houtsoorten van Suriname". (6) neergelegd.

Toen er nu eindelijk voortgang was gekomen in de voorbereiding van Suriname's houtexport, maakte een onverwachte gebeurtenis plotseling een einde aan de proefnemingen in de praktijk, waarvan in de vijfde conclusie van den ingenieur van den Broek sprake is: het Boschwezen in Suriname werd in 1925 opgeheven. Verschillende particuliere ondernemingen hadden in dien zelfden tijd zeer te klagen over te Le Hâvre en in Nederland aangevoerd minderwaardig hout. De afwezigheid van een des- 
kundige instantie, die in het belang der Kolonie controle op den houtexport zou hebben kunnen uitoefenen, deed zich nijpend gevoelen, terwijl het zich nu liet aanzien, dat de geheele op het gebied van houtonderzoek verrichte arbeid nutteloos was geweest. Deze toestand gaf de voornoemde, door het Koloniaal Instituut ingestelde, Commissie aanleiding tot het voorstel haar deskundige naar Suriname uit te zenden, ten einde het Bestuur advies uit te brengen over den meest geschikten vorm van bemoeienis van het gouvernement met boschexploitatie en houthandel. De Minister van Koloniën kon zich met het voorstel vereenigen en verstrekte aan Dr. Ir. J. Ph. Pfeiffer een desbetreffende opdracht, door hem als adviseur in zake houtkapaangelegenheden aan den Gouverneur van Suriname toe te voegen. Reeds veertien dagen na zijn aankomst in Suriname, op 11 October 1926, deed hij aan den Gouverneur zijn werkprogramma toekomen, dat daarna nagenoeg geheel ten uitvoer werd gebracht. (Bijlage III van het rapport (7).)

De verrichte werkzaamheden omvatten behalve het instellen van een onderzoek naar den aard van de bosschen welke in de eerstkomende decennia voor exploitatie in aanmerking zouden kunnen komen en naar de plaatselijke omstandigheden der houtexploitatie, o.m. een poging den afzet van paalhout te stimuleeren, door verbetering van de kwaliteit, zoowel wat bekapping als selecteering betreft.

Onder zijn leiding werden eenige proefpartijen Mora en Manbarklakpalen door de firma C. Kersten \& Co. samengesteld, die voldeden aan de eischen, die de Rijkswaterstaat in Nederland aan zulke palen stelt. Op grond van de ervaring met deze partijen opgedaan, heeft de firma Alberts, die in Nederland als vertegenwoordiger van de firma C. Kersten \& Co optrad, een contract gesloten met de Directie van de Zuiderzeewerken, voor de levering van een groote partij Manbarklak-palen, waarbij werd bepaald dat, wanneer men in gebreke zou blijven een deel der palen te leveren, de partij zou worden gecompleteerd met Demerara greenheart.

Spoedig na het vertrek van Dr. Pfeiffer ging het in het bosch uitgeoefende toezicht op den aankap en de keuring achteruit en dientengevolge ook de levering van Manbarklak. Zoo moest het Surinaamsche hout opnieuw de plaats, die het van nature toekomt, afstaan aan het Demarara greenheart harer Britsche zusterkolonie.

Gedurende zijn onderzoek kwam Dr. Pfeiffer ten aanzien van het houtkapbedrijf tot de volgende conclusies: 
1. noodzakelijkheid der wederinstelling van een dienst van het Boschwezen;

2. het voeren van een voorzichtige, doch zeer degelijke propaganda voor de Surinaamsche houtsoorten, het daadwerkelijk beoordeelen van de uitbreiding van het afzetgebied en het bestrijden van oneerlijke concurrentie van andere tropische houtsoorten;

3. het medewerken tot de oprichting en instandhouding van een bedrijf, of combinatie van bedrijven, in staat om, onder voor het welslagen der boschexploitatie zoo gunstig mogelijke voorwaarden, een ernstige proef te nemen tot het verkrijgen van een modern exportbedrijf van duurzamen aard;

4. het invoeren van een verordening op den houtkap, aan de omstandigheden van den tegenwoordigen tijd aanpast, ruimte latend voor ontwikkeling in de toekomst.

Het verslag waarin deze juiste adviezen zijn opgenomen bevat eveneens de opgave van achtentwintig Surinaamsche houtsoorten, welker bruikbaarheid voor bijzondere doeleinden in de Mededeelingen XX van het Koloniaal Instituut te Amsterdam „De Houtsoorten van Suriname” wordt aangetoond. Dit alles echter strookte niet met het toen bij de regeering in Nederland heerschende inzicht. Had men de pogingen den export van hout in goede banen te leiden van de HH. Berkhout, v. d. Broek en Gonggrijp met de opheffing van het Boschwezen beantwoord, Dr. Pfeiffer is niet gelukkiger geweest; ook aan zijn op hetzelfde gebied liggenden arbeid werd de welverdiende waardeering onthouden. Een groot gedeelte van het aan den Minister van Koloniën uitgebracht rapport werd niet eens gepubliceerd en van de vier hierboven genoemde conclusies werd slechts aan de derde raadgeving gevolg gegeven; in 1929 werd de zoogenaamde Commissie de Graaff ingesteld.

Deze Commissie, waarvan de latere Minister van Koloniën tot voorzitter werd benoemd en waarbij Dr. Pfeiffer en Ir. Kempees, een vroegere directeur van openbare werken in Suriname, als leden fungeerden, adviseerde tot de oprichting van een groot houtbedrijf in Suriname, dat onder de naam West-Indische Houthandel zijn beslag heeft gekregen.

Intusschen was in Suriname een houtbedrijf op bescheidener schaal tot stand gekomen, dat reeds in 1929, dus een jaar voor de oprichting van voornoemd grootbedrijf, hout in Nederland aan de markt bracht en ook paalhout aan Curaçao leverde. Onder deze leveringen waren belangrijke hoeveelheden Basra- 
lokus, een houtsoort, die beloofde een geduchte concurrent van het Demerara greenheart te worden. Deze laatstgenoemde houtsoort, welke in Suriname slechts in onbelangrijke hoeveelheden voorkomt, wordt bij voorkeur bij den Rijkswaterstaat verwerkt en werd door een der leden van de combinatie De West-Indische Houthandel in Nederland ingevoerd.

Aan oppervlakkige beoordeelaars mogen de oprichting van bovengenoemde bedrijven een groote vooruitgang toegeschenen hebben, degenen echter die de wording der boschexploitatie vanaf de aanwijzingen van Dr. Berkhout tot de voorstellen van Dr. Pfeiffer hadden beleefd, wisten dat dit op zich zelf niet voldoende is, daar houtaankap en uitvoer zonder deskundige controle ter plaatse een groot gevaar voor den afzet der goede Surinaamsche houtsoorten oplevert.

De verantwoordelijke autoriteiten dachten echter anders over deze aangelegenheid, zij meenden dat, aan de hand van Dr. Pfeiffer's geschriften, door het Gouvernement aan den houtaankap en export de noodige leiding gegeven kon worden; vandaar de oprichting van De West-Indische Houthandel, het grootbedrijf met regeeringssteun, doch zonder deskundige voorlichting in de Kolonie. Voordat de zaak haar beslag gekregen had heeft nog een gebeurtenis plaats gevonden welke een schel licht op de door onbevoegd ingrijpen ontstane situatie werpt. In 1928 wilde een concern, waarin onder meer de Europeesche Bank te Amsterdam en een Rotterdamsche reederij vertegenwoordigd waren, er toe overgaan Matakkiehout (Symphonia globulifera Limm. F.) te verwerken. Een in Nederland wonend Surinaamsch hoofdambtenaar trad als adviseur op. Volgens hem zou men deze houtsoort vanaf de mondingen der rivieren tot diep in het land in overvloed aantreffen en zouden de aankap en de afvoer op geen groote moeilijkheden stuiten. Ik vertoefde in dien tijd met verlof in Nederland en kwam met de vooraanstaande personen der onderneming in aanraking. Aan mijn voorstelling der werkelijkheid, dat Matakkie in het zee- en brakwatergebied niet groeit, louter in zoetwatermoerassen voorkomt, wilde men geen geloof hechten. Toen ik kort daarop naar Suriname was teruggekeerd kwam ik tot de ontdekking, dat een hoofdambtenaar als agent voor de onderneming optrad en aan boschopzichters werkzaamheden in verband met de exploitatie van Matakkiehout had opgedragen. Doordat de onuitvoerbaarheid van het project spoedig bleek, was ook deze poging weer van de baan.

Duidelijker dan door dit staaltje van onbevoegde bemoeienis 
met Surinaamsche houtzaken kwam het ontbreken van een deskundige instantie eenige jaren later tot uiting, bij het zaaien van twijfel omtrent de goede eigenschappen van een Surinaamsche houtsoort. Het betrof de reeds hierboven genoemde Basralokus. Terwijl deze aangelegenheid, die destijds veel stof heeft opgejaagd, van groote beteekenis is voor de toekomst van den Surinaamschen houtexport in het algemeen, werpt zij tevens een eigenaardig licht op de wijze waarop koloniale vraagstukken van buitenaf opgelost worden. Zonder mij aan conclusies te wagen, of mij tot insinuatie te laten verleiden, zal ik trachten de geschiedenis van deze zaak weer te geven, door slechts te vermelden wat ik beleefd heb, door feiten te geven. Na het vernemen dezer feiten en door deze tegenover elkander te stellen, zal de lezer zelf in de gelegenheid zijn zich een oordeel te vormen.

Zooals wij reeds weten, heeft de houtvester J. W. Gonggrijp Basralokus bij den houthandel ingevoerd en is door in Suriname en aan de Atlantische en Pacifickust van Noord-Amerika genomen proeven aangetoond, dat deze houtsoort tegen paalworm bestand is.

Ten einde eenig overzicht der vermoedelijk aanwezige voorraden Basralokus te verkrijgen, werden door het Boschwezen van 1919 tot 1921 nu en dan opstandsopnamen verricht, die uitgewezen hebben dat in het heuvelland ten Oosten der Surinamerivier en aan de Sarakreek, overal daar waar men van Basralokusbosch spreekt, deze boom ongeveer $5 \%$ van den totalen opstand uitmaakt. In het rapport van Dr. Pfeiffer (blz. 22) wordt de voorraad Basralokushout ruwweg op $1.500 .000 \mathrm{~m}^{3}$ geschat.

In het nummer van 26 Augustus 1922 van De Ingenieur lezen wij: ,dat basralokus wel minder goed bestand is tegen de zeer virulente neoterado dan manbarklak, ongetwijfeld door een lager gehalte aan kiezelzuur en mindere hardheid, doch daarentegen Demerara greenheart in dit opzicht ver achter zich laat. Wat duurzaamheid aan weer en wind betreft doet basralokus, volgens de ervaring, waarover wij hier te beschikken hebben, zeker niet onder voor Demarara greenheart, terwijl het hout veel handelbaarder is dan zijn Engelsche concurrent". (8).

Gedurende de jaren 1923 en 1924 werd door den houtvester Gonggrijp onderzoek naar de verschillen in kiezelzuurgehalte van Basralokushout ingesteld. In verschillende streken van het land werden uit een groot aantal boomen houtmonsters gehakt, met de boomen gelijk genummerd en daarna naar het laboratorium te Paramaribo opgezonden. Door dit onderzoek is men 
te weten gekomen dat de drie hierboven opgegeven typen Basralokus in Suriname voorkomen. De overige resultaten van dit onderzoek zijn door de opheffing van het departement van Landbouw, waarbij het archief van het Boschwezen over drie verschillende departementen verspreid werd, zoek geraakt.

Een jaar na de opheffing van het Boschwezen verscheen mededeeling No. XXII van het Koloniaal Instituut te Amsterdam, „De Houtsoorten van Suriname” Deel I. Op blz. 262 hiervan, onder de vermelding der technische gegevens aangaande Basralokushout lezen wij, nadat het hout is beschreven als bestand tegen aantasting door paalworm, het volgende:

„Het hout is dus, behalve voor zeeweringen en sluiswerken, geschikt voor brugbouw, huisbouw en binnenbetimmeringen. Doordat het niet veel zwaarder is dan eiken- en teakhout, zal het deze houtsoorten voor binnenbetimmeringen, wagon- en scheepsbouw zeer goed kunnen vervangen".

In het najaar van 1926 maakte Dr. Pfeiffer een aanvang met het reeds hierboven vermelde onderzoek en negen maanden later heeft op zijn aanwijzingen de exploratie der Basralokusbosschen ten Oosten der Surinamerivier plaats gehad. De verkregen resultaten waren goed en, omdat de ondernemers (afgaande op het oordeel der HH. Kempees en Gonggrijp en de goede meening van Dr. Pfeiffer omtrent Basralokus) overtuigd waren, dat deze houtsoort in plaats van een buitenlandsche in Nederland een goede kans zou hebben, werd tot de stichting van het bedrijf Suhoza (Surinaamsche Houthandel en Zagerij) overgegaan.

Reeds in 1929 verscheepte dit bedrijf aanzienlijke partijen Basralokus naar Nederland en het liet zich toen aanzien alsof het Surinaamsche hout een kans had zijn Engelschen concurrent te verdringen. In hetzelfde jaar bracht de Commissie de Graaff haar rapport uit en besloot de regeering tot de oprichting van het reeds genoemde grootbedrijf. Dit laatste, de West-Indische Houthandel, was een combinatie der firma's C. Kersten en Co te Paramaribo, N.V. Houthandel v/h G. Albers te Middelburg en de N.V. Houtbereiding Gips te Dordrecht, waarbij Ir. Kempers als raadsman van de regeering werd benoemd. Binnen de aan den West-Indischen Houthandel verleende concessies worden geen Basralokuscomplexen van eenige beteekenis aangetroffen; het voornaamste object dezer onderneming vormen de Morabosschen en de terreinen waarop veel Manbarklak voorkomt. Buitendien moet opgemerkt worden, dat de firma Albers de eenige importeur van Demerara greenheart in Nederland is en het hoofd der firma 
in het najaar 1929 persoonlijk een onderzoek in Suriname ingesteld heeft.

Het volgende jaar werden in Nederland geruchten verspreid over de ondeugdelijkheid van Basralokushout. De raadsman voor het groothoutbedrijf, van wien men mag aannemen dat hem ook de belangen van het Surinaamsche hout in het algemeen ter harte zouden gaan, vond hierin aanleiding een onderzoek in te stellen.

Op zijn vraag berichtte de directeur van openbare werken in Suriname dat Basralokushout minder tegen weersomstandigheden bestand is en dat men er bij zijn departement slechte ervaringen mede opgedaan had.

In dit bericht wordt geen melding gemaakt van het voorkomen van verschillende variëteiten van Basralokushout, die onderling in hooge mate in deugdelijkheid verschillen, waardoor ook niet is komen vast te staan welk deel der door bovengenoemden hoofdambtenaar genoemde getallen op de goede houtsoort betrekking had.

De raadsman voor het groothoutbedrijf kon zelf bovendien weten dat in Suriname met hout genomen proeven of opgedane ondervindingen geen maatstaf vormen voor de gedragingen van het hout in gematigde klimaten, zooals dat van Nederland. Ingevolge het uit Suriname ontvangen bericht wierp deze deskundige nu plotseling zijn vroeger gekoesterde gunstige meening omtrent Basralokushout overboord. In een bericht aan den Directeur-Generaal van den Rijkswaterstaat schreef hij onder meer:

„Basralokus is een houtsoort, die in Suriname tamelijk veelvuldig voorkomt, maar er vóór den oorlog weinig of niet gebruikt werd. Vóór 1921, ongeveer, werd het op gouvernementswerken, naar ik meen, nimmer gebruikt.

Of dit zijn oorzaak vond in de reeds eerder gebleken mindere deugdelijkheid of wel een gevolg was van onvoldoende kennis van de goede eigenschappen, weet ik niet. Naar de thans ontvangen berichten, moet ik overhellen tot de eerste meening".

Toen de in Nederland tegen het Basralokushout gevoerde actie in Suriname bekend werd, veronderstelde men aldaar dat de souschef van het departement openbare werken, Ir. van Wouw, voor de onvolledige voorlichting verantwoordelijk gesteld moest worden. In een brief gedateerd Paramaribo 8 December 1930, gericht aan de firma Surinaamsche Houthandel en Zagerij, heeft Ir. van Wouw hiertegen stelling genomen. In de eerste plaats 
vestigde hij de aandacht op het feit dat hij nog kort te voren op Curaçao het gebruik van Basralokushout nadrukkelijk had aanbevolen. Vervolgens deelde de deskundige mede, dat Basralokus in Suriname als dekplanken wel eens een slecht resultaat heeft opgeleverd. Eenige sluisdeuren hadden zich goed gehouden, terwijl bij andere schimmelvorming en rotting zijn opgetreden. Als schoothout der sluizen en als schuiven voor de sluisdeuren gedraagt zich basralokushout goed. Daarentegen werden bij reparaties aan een steiger te Paramaribo met Basralokushout wederom tegenslagen ondervonden. $\mathrm{Er}$ ontstond toen langzamerhand bij het technisch personeel een tegenzin tegen Basralokushout, want niemand ziet graag werk na drie jaren te niet gaan.

„Ik heb echter juist gemeend", zoo vervolgde Ir. van Wouw in den brief, ,,daar niet aan toe te moeten geven en uiterst voorzichtig te moeten voortgaan, daar men zich niet door een enkel geval algemeen kan laten leiden. Daar deed ook aan mee, dat vele deskundige houtkenners, wetende, dat ik in deze kwestie zat, mij erop attent makkten, dat er twee soorten roode en witte basra-lokus bestonden".

Het feit, dat voornoemde deskundige toezegde een onderzoek naar het verschil te zullen instellen, toont aan, dat men voorheen geen aandacht aan de kwaliteit van het gebruikte hout had geschonken en de mededeelingen omtrent de deugdelijkheid daarvan daarom niet als bewijsgronden voor het slechte gedrag van de goede soort Basralokus kunnen worden aanvaard.

Bedenkelijk, met het oog op de zoo moeizaam opgebouwde reputatie van het Surinaamsche hout, moet de openbare actie tegen een der soorten genoemd worden, welke van De WestIndische Houthandel uitgegaan is. In een aan de leden der Tweede Kamer toegezonden brochure aangaande de boschexploitatie in Suriname, van de genoemde combinatie uitgegaan, werd het Basralokushout ten onrechte in een ongunstig daglicht geplaatst, waardoor tevens het wetenschappelijk houtonderzoek in discrediet gebracht werd.

Het laatste eischt eenige toelichting. De lezer van genoemde brochure komt onvermijdelijk onder den indruk dat de ervaringen met Basralokus, door Openbare Werken in Suriname opgedaan, in tegenspraak zijn met het wetenschappelijk onderzoek. Dit is echter niet juist. Door de Heeren E. J. Kempees en J. W. Gonggrijp werd in 1922 betoogd (zie hierboven), dat basralokus, wat duurzaamheid in wind en weer betreft, volgens hun ervaring 
niet onderdeed voor Demerara greenheart. Dit oordeel is gebaseerd op een kortstondige praktische ervaring. Door de Commissie van Advies en Onderzoek inzake Surinaamsche Houtsoorten verrichte onderzoekingen toonden ondubbelzinnig aan, dat Basralokus in duurzaamheid bij het Demerara greenheart ten achter staat en dan ook in de waardeklasse If is ingedeeld, terwijl het laatste in waardeklasse I is ondergebracht (Surinaamsche Houtsoorten deel II blz. 262 resp. 145).

Omdat echter Basralokushout belangrijk duurzamer is dan eikenhout werd het voor de hierboven vermelde doeleinden, in het bijzonder voor toepassingen in Europa, aanbevolen. (Zie technische gegevens van Basralokushout blz. 262 ,De Houtsoorten van Suriname").

Een ander gevolg van de deining, die ontstaan was door deze Basralokusaffaire, was dat de Kon. Ver. Koloniaal Instituut meende de zaak van het Surinaamsche hout te moeten dienen door een reorganisatie der Commissie van Advies en onderzoek inzake Surinaamsche Houtsoorten te ondernemen en daarbij alle leden die op een of andere wijze commercieel belang hadden bij het Surinaamsche hout te verzoeken hun ontslag te nemen. Dit geschiedde dan ook in Maart 1933, onder het uitspreken van de verwachting dat de belangen van het Surinaamsche hout beter gediend zouden kunnen worden. Deze sterk gereduceerde commissie, waarvan, om volkomen onnaspeurlijke redenen, Dr. Pfeiffer noch als lid noch als deskundige deel uitmaakte, is echter door deze aderlating volkomen dood gebloed. Men heeft sedert nooit meer iets van haar gehoord; waarschijnlijk heeft zij zelfs nooit meer vergaderd. Daarmede was een ander stuk werk, dat van groot belang had kunnen zijn voor de exploitatie en den afzet van Surinaamsch hout, ontijdig en abrupt afgebroken.

Uit het hier onmiddellijk aan voorafgaande kan worden afgeleid, dat voor den goeden gang van zaken bij den houtexport uit Suriname het bestaan van een aan de bijzondere eischen van dat land beantwoordenden dienst van een boschwezen volstrekt noodzakelijk is. Daarmede is echter niet alles gezegd; het cardinale punt van het probleem der houtexploitatie is en blijft voorloopig het arbeidersvraagstuk. Dat het laatste bestaat, dat er gebrek aan geschikte houtbewerkers is, heeft zijn oorzaak in de eerste plaats in de dunne bevolking van Suriname. Nochtans zou het ten opzichte van de arbeidsprestaties bij den houtkap beter gesteld kunnen zijn, wanneer alle bevolkingsgroepen waaruit houtkappers gerecruteerd kunnen worden in het geregelde 
economische leven der kolonie waren ingeschakeld. Dit is niet het geval; de geboren houtkappers, de Boschnegers, zoeken hun bijverdiensten niet in den houtkap, doch in de vrachtvaart in de naburige koloniën. Gedurende een in 1923 naar de economische toestanden bij de Boschnegers ingesteld onderzoek bleek, dat alleen van de aan de Boven Suriname levende Saramaccanen zich 2000 mannen in Cayenne ophielden.

Ik deel de meening van Dr. Pfeiffer, dat er door een meer intensief bestuur veel bij de Boschnegers bereikt kan worden. In deze aangelegenheid is het gebrek aan continuiteit bij Surinaamsche bestuurszaken scherp naar voren gekomen. Onder het bestuur van Baron van Heemstra werd niet slechts politiek ingegrepen, doch ook getracht van de Boschnegers als producenten bij den houtkap partij te trekken. In de volgende bestuursperiode heeft men, als maatregel van bezuiniging, het contact met de Boschnegers weder volkomen verbroken; zoodoende moet er, wil men hen als betrouwbare arbeidskrachten bij den houtkap inschakelen, weder van voren af begonnen worden.

De overige bevolkingsgroepen welke voor den houtaankap in aanmerking komen, de aan de bovenrivieren wonende Indianen en Creolen, zijn in werkelijkheid ook slechts gelegenheidsarbeiders; van een organisatie ten behoeve der houtexploitatie is geen sprake.

Dr. Berkhout heeft, toen hij tot den proefaankap van gouvernementswege adviseerde, getoond een goed begrip van den toestand te bezitten; hij wilde, instede van de inheemsche, onbetrouwbare productie-elementen, iets nieuws brengen, door den Javaan als kolonist in de nabijheid van de voor de proefexploitatie in aanmerking komende boscharealen te vestigen. Een organisatie echter in dezen zin zou destijds alleen aan de daaraan gestelde verwachting hebben kunnen beantwoorden, wanneer men, buiten de contractueele immigratie om, tot vrije kolonisatie van Nederlandsche onderdanen uit Java ware overgegaan. De bovengenoemde immigratie was toen nog geen tien jaren oud en de meeste toen ter tijd reeds van contract vrij gekomen immigranten waren zoowel voor den landbouw als ook voor de boschexploitatie weinig geschikte elementen. Gaandeweg veranderde dit; naar mate op Java beter toezicht op de voor Suriname bestemde immigranten werd uitgeoefend, kwamen ook betere arbeiders in Suriname terecht en werden onder hen ook geroutineerde kappers uit de Djatibosschen aangetroffen. Dit laatste bleek reeds bij de balatatapproeven in 1913; onder de aan de Sarakreek 
en elders in het binnenland te werk gestelde Javanen waren er vele, die bij het vellen der bolletrieboomen niet voor de Boschnegers onderdeden. Nog later is de geheele onder het Boschwezen ressorteerende aankap van brandhout in handen der Javanen gekomen. Als men weet dat het aantal Creolen en Indianen te gering is, om in de behoeften van den aankap voor export te voorzien en dat de Boschnegers altijd een onbetrouwbaar productie-element zullen blijven, dan gaat men het denkbeeld van Dr. Berkhout om houtkap en kolonisatie van Javanen samen te laten gaan, als voor de hand liggend zien.

Toen het uitzenden van contractarbeiders naar Suriname ophield, poogde het toenmalige bestuur van Suriname de immigratie door vrije kolonisatie te vervangen. In 1930 kwamen een dertigtal Javaansche gezinnen te Paramaribo aan, die aan den rand van het moerasgebied, verwijderd van stroomend water, werden gevestigd. $\mathrm{Na}$ een vijftal jaren verliep de kolonisatie en bijna alle mannen kwamen terecht bij den houtkap aan de BovenSuriname. Dit laatste is een directe aanwijzing van den weg dien het uit moet. Het huidige bestuur van Suriname volgt echter een anderen weg en heeft blijkbaar uit de ervaringen welke men gedurende de laatste dertig jaren met de Javaansche kolonisatie in de Kolonie heeft opgedaan geen leering getrokken. Men stelt zich voor de bergbewoners van Java polderboeren te doen worden, door hen in het zeekleigebied te vestigen, dat geen redelijke kansen aan boomcultures en bananen biedt, doch slechts de rijstcultuur als bestaansmogelijkheid aanwijst. Omdat voor de doorvoering der kolonisatie op groote schaal, volgens dezen gedachtengang, in Suriname nog geen uitgewerkt plan bestaat, en als de daarvoor noodzakelijke voorbereiding een kostbare en moeilijk uit te voeren irrigatie (9) wordt aanbevolen, is er nog tijd en gelegenheid het een en ander op te merken. In de eerste plaats vestig ik er de aandacht op dat ik reeds vroeger de Javaansche kolonisatie als een onderdeel der Europeesch-Javaansche kolonisatie in Suriname heb besproken. Het ging toen echter uitsluitend over landbouw. Sedert hebben zich echter de omstandigheden geheel anders ontwikkeld: Suriname is in Nederland in het brandpunt der belangstelling komen te staan en in de V.S. werd men in de gelegenheid gesteld met de in Suriname heerschende toestanden nader kennis te maken. Gezien de steeds grooter afmetingen aannemende behoefte aan hard hout, kan het laatste van bijzondere beteekenis voor de boschexploitatie worden Om dit te begrijpen moet men het volgende bedenken: In de Vereenig- 
de Staten van Noord-Amerika is het vraagstuk der geregelde voorziening van hard hout acuut geworden. Sommige schrijvers schatten dat tegen het einde van deze eeuw de voornaamste bosschen van de Vereenigde Staten uitgeput zullen zijn, terwijl het midden van de twintigste eeuw wordt genoemd als het tijdstip, waarop de loofhoutbosschen (hardwood-forests) niet meer zullen kunnen produceeren.

W. V. Sparhawk schrijft bijvoorbeeld in 1925 onder den titel „Why the United States is interested in Latin-American Forest development”: (10) „It seems to be almost inevitable then, if we are to have adequate supplies of high grade hardwood timber after the next 20-30 years, that we shall have to import large quantities, at least for the following 50 years".

Veel Amerikaansche houtexperts zijn echter huiverig om met tropische boschexploitatie te beginnen en dat voornamelijk omdat zich de tropische bosschen met hun groot aantal soorten niet leenen voor de Amerikaansche boschexploitatie-methoden. Ook de bedrijven die gebaseerd zijn op massaproductie leenen er zich zonder radicale wijzigingen niet toe de veel hardere tropische loofhoutsoorten te verwerken. Het is echter hoogst waarschijnlijk dat men in Amerika zal inzien, dat de onmisbare hoeveelheid hardhout uit de tropen betrokken zal moeten worden en dat men er toe zal overgaan de exploitatiemethoden te wijzigen

Deze omstandigheden openen een perspectief voor den houtexport van Suriname. Daarbij komt, dat redelijkerwijs verwacht mag worden dat de waterstaat, de spoorwegen en gemeentewerken zich voortaan niet meer in hoofdzaak naar het oordeel van enkele, slechts ten deele bevoegde personen zullen richten, doch veel meer de door wetenschappelijk onderzoek verkregen gegevens tot richtsnoer zullen nemen, zoodat voor de boschexploitatie in Suriname een nieuw tijdperk kan aanbreken. Zoowel in Amerika als ook in Nederland zal men echter waarborgen omtrent kwaliteit en leveringstermijnen willen hebben; men zal de keuring van het hout door een deskundige instantie eischen, voorvallen, zooals hierboven ten aanzien van Basralokus en andere houtsoorten beschreven werden, moeten onmogelijk worden, m.a.w. de wederinvoering in Suriname van een voor zijn taak berekend boschwezen moet als volstrekt noodzakelijk beschouwd worden.

Een geordende boschexploitatie kan het niet zonder een gezeten bevolking stellen en deze het wederom niet buiten landbouw, zoodat het vraagstuk in wezen een agrarisch-boschbe- 
stuurkundig probleem blijkt te zijn. De oplossing daarvan levert groote moeilijkheden op, omdat men in Suriname met eene primitieve bevolking te doen heeft, tegenover welke het bestuur der Kolonie een zeer eigenaardige houding aanneemt. Terwijl het eene bestuur tracht de Boschnegers beter bij het economische leven der Kolonie in te schakelen en in het bijzonder den houtkap als het middel beschouwt om dit doel te bereiken, verbreekt een volgend bestuur weer het moeizaam verkregen contact met deze oerwoudbewoners. De duizenden Boschnegers en honderden Indianen en Creolen die den houtkap uitoefenen, kunnen in sommige jaren niet eens in de behoeften van de locale houtmarkt voorzien. In sommige jaren heerscht zelfs voedselschaarschte bij hen. Het zou te ver voeren hier op de oorzaken van deze toestanden, welke in verregaande zorgeloosheid, eigenaardige rechtsbegrippen en in psychische gesteldheden en opvattingen van deze bevolkingsgroepen gezocht moeten worden, nader in te gaan. Er moge slechts opgemerkt worden dat, zoolang nog geen verandering gebracht is in de opvattingen van het bestuur, de genoemde bevolkingsgroepen nog voor langen tijd als onbetrouwbare houtkappers aangemerkt zullen moeten worden.

Er bestaat echter de mogelijkheid den uitbouw der boschexploitatie voor de toekomst veilig te stellen. Zooals reeds gezegd is, heeft gedurende de twee laatste bestuursperioden van Suriname het denkbeeld van een vrije Javaansche kolonisatie ingang gevonden en dit denkbeeld werd door het opperbestuur overgenomen. De houtkap schept voor deze kolonisten een bestaansmogelijkheid, terwijl een tweede bron van inkomsten gevonden kan worden in de hulpverleening aan de in het heuvelland door te voeren citruscultuur. Doordat de Javanen als geroutineerde landbouwers in het vruchtbare heuvelland gemakkelijk in hun eigen voeding kunnen voorzien en bovendien nog eenige stapelgewassen zooals de in Amerika gewenschte bananensoort, cacao, tabak enz. kunnen verbouwen, zal het succes der kolonisatie slechts van haar goede organisatie afhankelijk zijn. De hier bedoelde regeling van landbouw en houtkap in de onbewoonde heuvelterreinen zal later door een andere regeling betreffende werkzaamheden in het boschnegergebied gevolgd kunnen worden.

Het verwezenlijken der hierboven genoemde denkbeelden zou een flinke stap vooruit op den weg der economische ontwikkeling van Suriname beteekenen en bovendien nog de volgende voordeelen met zich brengen:

1. De op wetenschappelijk onderzoek gebaseerde ervaring, 
evenals de in jarenlangen, moeizamen arbeid opgebouwde gunstige reputatie van het Surinaamsche hout, zal voor de kolonie nuttig effect hebben;

2. De bevolking van Suriname zal dan een voor den economischen opbouw gewenschten versterking met Nederlandsche onderdanen uit de tropische gebiedsdeelen van het Rijk verkrijgen;

3. Door de vestiging der Javanen op het hooge land zou de problematische en op den duur zeer kostbare irrigatie althans in den aanvang overbodig zijn.

Bovenstaande beschouwingen maken er geen aanspraak op een gedegen, in alle opzichten deskundige studie te zijn; het zijn louter de herinneringen aan wederwaardigheden en ervaringen van ruim twintig jaren dienst bij het Boschwezen en de Boschpolitie in Suriname. Ze werden echter op schrift gesteld met het doel op dit bijzondere tijdstip nog eens de aandacht te vestigen op hetgeen in het verleden in het belang der boschexploitatie in dit gebiedsdeel werd verricht en op de omstandigheden, welke het bereikte voor een belangrijk deel te loor hebben doen gaan, alsmede op de invloeden welke daartoe gewild of ongewild hebben bijgedragen.

Wellicht kunnen zij ook dienen als een aanwijzing voor de wijze waarop in de toekomst op het goede dat verricht werd kan worden verder gebouwd en de bekende klippen kunnen worden omzeild.

Hilversum, Augustus 1944.

Lit t e ratu ur:

(1) A. H. Berkhout, Rapport over de Surinaamsche bosschen, Den Haag 1904.

(2) A. H. Berkhout, Rapport over het Surinaamsche Boschwezen, Den Haag 1917.

(3) Ir. E. K. Plasschaert, Der Forstbetrieb in Surinam, München 1912.

(4) J. W. Gonggrijp, Bulletin No. 48 Departement van Landbouw, Paramaribo Maart 1925.

(5) G. J. van den Broek, Bevordering van den afzet van Surinaamsch hout in Nederlana, 's-Gravenhage 1917.

(6) Kol. Instituut XXII-6, 1926 en 1927.

(7) Dr. Ir. J. Ph. Pfeiffer. Algemeene Landsdrukkerij, 's-Gravenhage 1929. 
(8) Ir. E. J. Kempees en J. W. Gonggrijp, Basra-Lokus of Angelique (Dicorynia Paraensis) een verwaarloosde houtsoort ter vervanging van Demarara-greenheart.

(9) L. Junker, Het irrigatie vraagstuk in Suriname, De WestIndische Gids Jaarg. 22 No. 7/8.

(10) W. V. Sparhawk, Pan American Union, Forestry No. 41925. 